\title{
Systemic Therapy for Metastatic or Recurrent Squamous Cell Carcinoma of the Head and Neck
}

\author{
A. Dimitrios Colevas, MD
}

\begin{abstract}
This article summarizes the systemic treatment options for patients with recurrent and/or metastatic squamous cell carcinoma of the head and neck, with an emphasis on recommendations based on phase II and III comparison trials of commercially available agents. Many single-agent and combination regimens have activity against these cancers, but improvement in overall survival remains a challenge, and median survivals in this population with best available therapy remain less than 1 year. The major recent advancement has been the introduction of epidermal growth factor receptor inhibitors, with mixed success. Although single-agent treatment with methotrexate, paclitaxel, docetaxel, or 5-fluorouracil remains one standard for many patients, the use of cisplatin- or carboplatin-based multidrug regimens that include cetuximab has become more popular, primarily based on one randomized study demonstrating a modest survival improvement of approximately 3 months associated with the addition of cetuximab. The burdensome adverse event profile of multidrug regimens makes appropriate patient selection for such aggressive treatment challenging, and consideration should include factors such as need for palliation, performance status of the patients, history of prior treatment, convenience, and cost. Genetically targeted and immunologically mediated treatments are promising but remain experimental. Given the worrisome prognosis for these patients, innovative clinical trials are a good option for many patients and deserve support. (J Natl Compr Canc Netw 2015;13:e37-e48)
\end{abstract}

From Stanford University School of Medicine, Stanford, California. Submitted May 14, 2014; accepted for publication November 5, 2014.

Dr. Colevas has disclosed that he serves on the advisory board of the Afatinib trial sponsored by Boehringer Ingelheim.

Correspondence: A. Dimitrios Colevas, MD, Sanford Cancer Institute 875 Blake Wilbur Drive, Stanford, CA 94305.

E-mail: colevas@stanford.edu
The global burden of squamous cell carcinoma of the head and neck (SCCHN) is substantial. In 2014, an estimated 55,000 new cases were diagnosed in the United States and 500,000 globally, accounting for approximately $5 \%$ of the domestic and $8 \%$ of the global burden of new cancers. ${ }^{1,2}$ A substantial portion of these cancers are preventable through tobacco consumption interdiction and reduction in exposure to indoor smoke from sources such as such as wood burning stoves. ${ }^{3}$ In the United States, for example, a decline has already occurred in the incidence of most upper aerodigestive cancers, including SCCHN. ${ }^{1}$ One notable exception to this is the exponential increase in the incidence of oropharyngeal SCCHNs, related to an increase in human papillomavirus (HPV)-associated oropharyngeal SCCHNs. ${ }^{4} \mathrm{HPV}$-related SCCHNs may also be preventable through vaccination strategies analogous to those for the prevention of uterine cervix cancers.

Despite this long-range optimism regarding prevention of many SCCHNs through vaccination against HPV and reduction of tobacco consumption domestically and globally, the burden of incurable disease remains high and is likely to remain so for the next few decades. Approximately half of all patients with SCCHN eventually die of their cancer, either because they have incurable metastatic disease at diagnosis or they experience disease relapse after attempts at curative treatment. ${ }^{5}$

Several randomized controlled trials have been performed in patients with recurrent or metastatic SCCHN over the past 30 years, with the most common design comparing a single agent with combination therapy. However, these randomized comparisons of different drug options are far from exhaustive, and data from uncontrolled clinical trials and expert clinician experience are regularly considered in clinical decision-making. It can be difficult to compare the clinical benefit of dif- 
ferent options because patient characteristics and history of prior therapy can vary widely among studies, and therapies used when a patient comes off a study are typically not reported, which confounds the interpretation of an overall survival (OS) end point. In addition, legacy studies were performed in an era during which the methodological standards for studies were both different and at times less rigorous compared with those of more modern studies. For example, many older studies have not used what are accepted now as rigorous criteria for response assessment, such as the RECIST system. ${ }^{6}$ Many studies only report response rates (RR) or progression-free survival (PFS), not both. Patients who experience disease relapse soon after chemoradiation are unlikely to derive substantial benefit from treatment using agents incorporated into the original chemoradiation regimen. Clinical trial reports are often vague about prior treatments, prior treatment responses, and time from prior treatment to the development of recurrent and/or metastatic SCCHN. Therefore, there can be considerable uncertainty concerning the anticancer activity that can be expected for an individual patient based on these reports.

Today most experts agree that the most clinically meaningful and robust outcome measurements are OS and PFS rather than tumor response rates. In the absence of analyses supporting a strong association between response rates and quality of life, one must be cautious about the assumption that higher RRs are associated with clinical benefit, especially because the higher RRs for cytotoxic agents are obtained at the price of a more burdensome adverse event profile, and improvement in OS compared with bettertolerated single agents has proved elusive. Therefore, whether patients with recurrent or metastatic disease are best served by concurrent multidrug treatment or sequential administration of individual chemotherapy agents is unclear.

Randomized trials that demonstrate improvement in survival compared with best supportive care or other drug therapy are rare, 7,8 and the demonstrated survival advantage is a modest 2 to 3 months. Therefore, hope for OS improvement in the presence of recurrent or metastatic disease alone is not sufficient to justify routine immediate treatment with systemic agents in all patients, because most patients will experience a decrease in well-being unless those agents can relieve existing tumor-related symptoms.
Comparisons among treatments whose outcome differences in terms of OS and quality of life are modest, even though the costs of the compared therapy vary substantially, are fertile ground for costeffectiveness and related value assessments. These circumstances are applicable to patients receiving treatment for recurrent or metastatic SCCHN. Finally, despite average or median outcomes, it is clear that a significant minority of patients experience unquestionable benefit from systemic treatments for their recurrent or metastatic disease. Until better predictors for who will benefit become available, clinicians and patients must often make decisions with significant uncertainty regarding benefit of these choices, but clinicians should be vigilant with respect to avoiding a default position of therapeutic nihilism for all of these incurable patients.

\section{Single-Agent Uncontrolled Studies}

Several agents have demonstrated robust anticancer activity in patients with recurrent and/or metastatic SCCHN. In the past few years several reviews and overviews have been published concerning systemic treatments for patients with recurrent or metastatic SCCHN. ${ }^{9-15}$ The most robustly studied agents are cisplatin, carboplatin, methotrexate, 5-fluorouracil (5-FU), ifosfamide, paclitaxel, and docetaxel (Table 1). Response rates typically range from $10 \%$ to $30 \%$, with some outlier reports of higher response rates, typically in older, smaller studies in which patients had received no prior treatment. The choice between cisplatin and carboplatin is largely driven by one study that favored cisplatin over carboplatin when used in combination with 5-FU, based on superior response rates ( $32 \%$ vs $21 \%$, respectively) without significant survival differences. ${ }^{16}$ Carboplatin is widely regarded as the more tolerable of these 2 platinums. Other agents occasionally used and less well studied include bleomycin, vinorelbine, cyclophosphamide, hydroxyurea, and gemcitabine, which are typically associated with response rates of $10 \%$ to $20 \% .{ }^{17-20}$

Epidermal growth factor receptor (EGFR) inhibitors, both anti-EGFR monoclonal antibodies and small molecule tyrosine kinase inhibitors, have recently been studied in patients with recurrent and/ or metastatic SCCHN. When used alone, these agents generally have low levels of activity, with response 
Treatment of Metastatic Head and Neck Cancer

\begin{tabular}{|c|c|c|c|c|c|c|c|}
\hline Agent & $\mathbf{N}$ & $\begin{array}{l}\text { Prior Treatments } \\
\text { for Most }\end{array}$ & $\begin{array}{l}\text { RR } \\
(\%)\end{array}$ & $\begin{array}{l}\text { Median } \\
\text { OS } \\
\text { (mo) }\end{array}$ & $\begin{array}{l}\text { Median } \\
\text { PFS or TTP } \\
\text { (mo) }\end{array}$ & Comments & Reference \\
\hline Cisplatin & 26 & $S, R, C$ & 30 & NA & NA & $\begin{array}{l}240 \mathrm{mg} / \mathrm{m}^{2} \text { day } 1 \text { and } 5, \\
\text { surgery day } 12-15\end{array}$ & 58 \\
\hline Methotrexate & 30 & $\begin{array}{l}\text { None; neoadjuvant } \\
\text { trial }\end{array}$ & $77^{\mathrm{a}}$ & NA & NA & $\begin{array}{l}\text { Intravenous and oral, } \\
\text { various doses }\end{array}$ & 59 \\
\hline Methotrexate & 44 & Mixed & 66 & NA & NA & $\begin{array}{l}\text { dose levels } 5000,500, \\
50 \mathrm{mg} / \mathrm{m}^{2}\end{array}$ & 60 \\
\hline Methotrexate & 58 & Mixed & $\begin{array}{l}50,21, \\
31\end{array}$ & NA & NA & $\begin{array}{l}1250 \mathrm{mg} / \mathrm{m}^{2} \text { days } 1,8 \\
\mathrm{q} 21 \mathrm{~d}\end{array}$ & 61 \\
\hline Gemcitabine & 10 & $S, R, C$ & 37 & NA & NA & $250 \mathrm{mg} / \mathrm{m}^{2} \mathrm{q} 21 \mathrm{~d}$ & 62 \\
\hline Paclitaxel & 30 & $S, R, C(13 \%$ prior $C)$ & 40 & 9.2 & ТТР, 3.4 & $100 \mathrm{mg} / \mathrm{m}^{2}$ weekly & 63 \\
\hline Paclitaxel & 74 & $\begin{array}{l}\mathrm{S}, \mathrm{R}, \mathrm{C}(76 \% \text { prior } \\
\text { platinum) }\end{array}$ & 29 & 14.3 & TTP, 3.4 & 100 mg/m² weekly & 64 \\
\hline Docetaxel & 30 & $\begin{array}{l}\mathrm{S}, \mathrm{R}, \mathrm{C}(63 \% \text { prior } \\
\text { platinum) }\end{array}$ & 7 & 3.9 & PFS, 1.8 & $\begin{array}{l}35 \mathrm{mg} / \mathrm{m}^{2} \text { weekly, 3/4 } \\
\text { weeks }\end{array}$ & 65 \\
\hline Docetaxel & 23 & $\begin{array}{l}\mathrm{S}, \mathrm{R}, \mathrm{C}(100 \% \text { prior } \\
\text { platinum) }\end{array}$ & 13 & 6.9 & TTP, 2.1 & $\begin{array}{l}30 \mathrm{mg} / \mathrm{m}^{2} \text { weekly, } 4 / 5 \\
\text { weeks }\end{array}$ & 66 \\
\hline Docetaxel & 38 & $\begin{array}{l}\text { S, R, C ( } 45 \% \text { prior } \\
\text { platinum) }\end{array}$ & 42 & 11.3 & $\begin{array}{l}\text { Response } \\
\text { duration: } \\
\text { median, } 8.4\end{array}$ & $30 \mathrm{mg} / \mathrm{m}^{2}$ weekly & 67 \\
\hline Docetaxel & 31 & $\begin{array}{l}\text { S, R, C ( } 32 \% \\
\text { neoadjuvant } \\
\text { platinum) }\end{array}$ & 42 & NA & NA & $100 \mathrm{mg} / \mathrm{m}^{2} \mathrm{q} 21 \mathrm{~d}$ & 68 \\
\hline Docetaxel & 43 & $\begin{array}{l}\mathrm{S}, \mathrm{R}, \mathrm{C}(2 \% \\
\text { neoadjuvant cisplatin) }\end{array}$ & 30 & NA & NA & $100 \mathrm{mg} / \mathrm{m}^{2} \mathrm{q} 21 \mathrm{~d}$ & 69 \\
\hline Zalutumumab & 90 & Platinum-refractory & 5.7 & 5.3 & PFS, 2.1 & & 21 \\
\hline Cetuximab & 103 & Platinum-refractory & 13 & 5.9 & ТTP, 2.3 & & 22 \\
\hline Erlotinib & 35 & Neoadjuvant & $29^{\mathrm{a}}$ & NA & NA & $\begin{array}{l}\text { Rash predicted response; } \\
\text { EGFR expression did not }\end{array}$ & 70 \\
\hline Erlotinib & 115 & & 4.3 & 6 & PFS, 2.2 & $\begin{array}{l}\text { PS and rash predict } \\
\text { response and OS }\end{array}$ & 23 \\
\hline Gefitinib & 52 & $S, R, C$ & 10.6 & 8.1 & TTP, 3.4 & $\begin{array}{l}\text { Dose escalation titrated } \\
\text { to rash }\end{array}$ & 24 \\
\hline Gefitinib & 44 & $S, R, C$ & 7 & 5.1 & PFS, 1.9 & & 25 \\
\hline Vinorelbine & 24 & $\mathrm{~S}, \mathrm{R}, \mathrm{C}$ (24\% prior PF) & 22 & & $\begin{array}{l}\text { Response } \\
\text { duration, } 5.8\end{array}$ & & 71 \\
\hline Vinorelbine & 16 & $\begin{array}{l}\text { S, R, C ( } 94 \% \text { prior } \\
\text { platinum) }\end{array}$ & 6 & 4.3 & ТТР, 1.9 & & 72 \\
\hline S1 & 26 & NA & 46.2 & NA & NA & & 73 \\
\hline UFT & 42 & $S, R, C$ & 21 & 8.7 & NA & & 74 \\
\hline Capecitabine & 40 & $\begin{array}{l}\mathrm{S}, \mathrm{R}, \mathrm{C}(65 \% \text { prior } \\
\text { platinum) }\end{array}$ & 24 & 7.3 & TTP, 4.8 & & 75 \\
\hline Bleomycin & 298 & & 21 & & & & 17 \\
\hline 5-FU & 118 & & 15 & & & & 17 \\
\hline Hydroxyurea & 17 & & 29 & & & & 17 \\
\hline Ifosfamide & 36 & $\mathrm{~S}, \mathrm{R}$, no prior $\mathrm{C}$ & 28 & 6.8 & & & 76 \\
\hline
\end{tabular}

Abbreviations: 5-FU, 5-fluorouracil; C, chemotherapy; EGFR, epidermal growth factor receptor; NA, not available; OS, overall survival; PF, cisplatin plus 5-FU; PFS, progression-free survival; PS, performance status; R, radiation; RR, response rate; S, surgery; TTP, time to progression; UFT, uracil and ftorafur.

${ }^{a}$ Neoadjuvant means no prior treatment. 
rates of $5 \%$ to $10 \%$ and correspondingly short PFS and OS intervals. ${ }^{21-25}$ Trials designed to escalate dose to acneiform rash as a surrogate pharmacodynamics marker have demonstrated no improvement in clinical activity beyond what was previously reported in trials using fixed-dose regimens, suggesting that dose optimization according to titration to rash is not beneficial. ${ }^{25,26}$

\section{Single-Agent Randomized Trials}

Table 2 summarizes the data from selected randomized trials for patients with recurrent and/or metastatic SCCHN. Outcomes reported from these clinical trial are summarized herein.

Only 2 studies have compared any of these agents to a best supportive care (BSC) arm. In 1985, Morton et $\mathrm{al}^{7}$ published a $2 \times 2$ factorial design study of BSC versus bleomycin versus cisplatin versus bleomycin plus cisplatin. In this 116-patient study, no statistically significant differences in RR or OS were observed, except in the pooled analysis of cisplatincontaining arms versus the others, in which the median OS was 4.3 months with cisplatin versus 1.8 months without. This early study established cisplatin as the standard (alone or in combination) drug against which many subsequent agents have been tested. Machiels et $\mathrm{al}^{26}$ compared zalutumumab, an experimental anti-EGFR monoclonal antibody, with BSC in 286 patients who had prior platinum exposure. The RR to zalutumumab was low at $6.3 \%$, and the median OS (6.7 months) was not statistically different from that of BSC. This response rate approximates that of other anti-EGFR tyrosine kinase inhibitors and monoclonal antibodies (Table 1), suggesting a minor role, if any, for EGFR-targeted therapy alone.

Direct comparison of methotrexate versus cisplatin has yielded no clear winner, with modestly powered studies demonstrating numerical superiority of either cisplatin or methotrexate in terms of RR and median survival, depending on the study. No consistent pattern of superiority has been seen for either agent. ${ }^{16,27-29}$ A large trial comparing methotrexate with 2 dosage regimens of gefitinib in patients either unsuitable for or who experienced disease relapse after treatment with cisplatin similarly failed to demonstrate superiority for either therapy, with all arms' RR less than $10 \%$ and median survival ap- proximately 6 months. ${ }^{30}$ Additionally, a large study comparing cisplatin with 5-FU demonstrated no response or survival superiority for either agent. ${ }^{31}$ One small trial of methotrexate versus docetaxel in the first-line recurrent setting demonstrated no differences in RR, PFS, or OS. ${ }^{32}$

Therefore, when deciding among these agents for single-agent treatment, data concerning antitumor efficacy does not offer much guidance. The most consistent and robust data are for cisplatin, methotrexate, and 5-FU, but the taxanes also probably should be considered. Although cetuximab is FDAapproved as a single agent in this setting, a 13\% response rate, no evidence of superiority, and a dramatically higher price suggest that this agent should not be chosen over the others.

\section{Multiagent Randomized Trials}

A few dozen trials of multiagent chemotherapy have been performed in patients with recurrent and/or metastatic SCCHN. Tables 2 and 3 provide a summary of controlled and uncontrolled trials. Most of the randomized trials are small studies that have compared a methotrexate- or cisplatin-containing arm with something else. A major weakness with many of these studies is that they were inadequately powered to detect survival improvements. For example, to detect a 3-month (6 vs 9 months) difference in survival between 2 arms accruing over 2 years with a power of 0.9 , more than 130 patients would need to be enrolled on each arm. Most randomized controlled trials of systemic chemotherapy fail to meet this adequate sample size criterion. Notably, of the 7 trials in Table 2 that have at least 130 patients per arm, only 1 yielded a statistically significant OS result. Subsequent therapy when a patient comes off study is typically not documented, which may also contribute to the lack of significant impact on OS.

Generally, response rates to combinations are higher than to single agents, but these higher response rates are associated with worse adverse event profiles and, with one exception, have not translated into survival improvement. The doublets of cisplatin plus methotrexate (PM), cisplatin plus 5-FU (PF), and cisplatin plus paclitaxel (PT) are all roughly equivalent in terms of response rates and survival. ${ }^{29,33,34}$ The comparison of PF and PM demonstrated approximately numerically similar adverse 
Treatment of Metastatic Head and Neck Cancer

\begin{tabular}{|c|c|c|c|c|c|c|c|}
\hline Agents & $\mathbf{N}$ & $\begin{array}{l}\text { Prior } \\
\text { Treatments } \\
\text { for Most }\end{array}$ & $\begin{array}{l}\text { RR } \\
(\%)\end{array}$ & $\begin{array}{l}\text { Median } \\
\text { TTP or PFS } \\
\text { (mo) }\end{array}$ & $\begin{array}{l}\text { Median } \\
\text { OS } \\
(\mathrm{mo})\end{array}$ & Comments & Reference \\
\hline MTX vs CDDP & 44 & $\mathrm{~S}, \mathrm{R}$ & 24 vs 29 & 2.8 vs 3.0 & 6.1 vs 6.3 & $\begin{array}{l}87 \% \text { emesis with } \\
\text { CDDP }\end{array}$ & 27 \\
\hline $\begin{array}{l}\text { MTX vs CDDP + } \\
\text { vincristine + B }\end{array}$ & 61 & $\mathrm{~S}, \mathrm{R}$ & 33 vs 41 & & 5.5 vs 4.0 & $\begin{array}{l}\text { Cost per course } \\
\text { plus } \$ 197 \text { vs } \$ 852\end{array}$ & 38 \\
\hline MTX vs CDDP & 100 & $\begin{array}{l}S, R, \text { no } \\
\text { prior C }\end{array}$ & 16 vs 8 & $\begin{array}{l}\text { Response } \\
\text { duration } 4.5 \\
\text { vs } 2.0\end{array}$ & 4.6 vs 4.0 & & 28 \\
\hline $\begin{array}{l}\text { MTX vs MTX + B + } \\
\text { CDDP }\end{array}$ & 163 & $S, R$ & 35 vs 48 & 5.0 vs 5.8 & 5.6 vs 5.6 & & 77 \\
\hline $\begin{array}{l}\text { MTX vs CDDP + } \\
\text { vinblastine + B }\end{array}$ & 191 & & 16 vs 24 & 4.6 vs 3.4 & 7.1 vs 6.7 & & 78 \\
\hline $\begin{array}{l}\text { CDDP vs CDDP + } \\
\text { MTX }\end{array}$ & 80 & $\mathrm{~S}, \mathrm{R}$ & 18 vs 33 & & 6.3 vs 6.9 & $\begin{array}{l}\text { More AEs in } \\
\text { combination, } \\
\text { especially } \\
\text { leucopenia and } \\
\text { mucositis }\end{array}$ & 79 \\
\hline $\begin{array}{l}\text { MTX vs CDDP vs } \\
\text { CDDP + MTX vs } \\
\text { CDDP + 5-FU }\end{array}$ & 124 & & $\begin{array}{l}19 \text { vs } 40 \text { vs } \\
31 \text { vs } 33\end{array}$ & & $\begin{array}{l}2.7 \text { vs } 8.7 \text { vs } 5.3 \\
\text { vs } 6.7\end{array}$ & $\begin{array}{l}\text { OS significantly } \\
\text { different only } \\
\text { MTX vs CDDP }\end{array}$ & 33 \\
\hline $\begin{array}{l}\text { Control vs B vs } \\
\text { CDDP vs CDDP + B }\end{array}$ & 116 & $\mathrm{~S}, \mathrm{R}$ & $\begin{array}{l}\text { NA vs } 14 \text { vs } \\
24 \text { vs } 13\end{array}$ & & $\begin{array}{l}\text { No significant } \\
\text { difference } \\
\text { except CDDP } \\
\text { vs control, } 4.3 \\
\text { vs } 1.8\end{array}$ & $2 \times 2$ trial design & 7 \\
\hline $\begin{array}{l}\text { CDDP + 5-FU vs } \\
\text { CBCDA + 5-FU vs } \\
\text { MTX }\end{array}$ & 277 & $\mathrm{~S}, \mathrm{R}$ & $\begin{array}{l}32 \text { vs } 21 \\
\text { vs } 10\end{array}$ & & 6.6 vs 5.0 vs 5.6 & & 16 \\
\hline MTX vs MTX + 5-FU & 48 & $\mathrm{~S}, \mathrm{R}$ & 25 vs 58 & & 6.2 vs 8.1 & & 80 \\
\hline $\begin{array}{l}\text { CDDP vs CDDP + } \\
\text { vincristine + MTX } \\
+B\end{array}$ & 209 & $\mathrm{~S}, \mathrm{R}$ & 15 vs 30 & $\begin{array}{l}\text { No significant } \\
\text { difference }\end{array}$ & $\begin{array}{l}\text { No significant } \\
\text { difference }\end{array}$ & $\begin{array}{l}\text { CDDP arm much } \\
\text { better tolerated }\end{array}$ & 81 \\
\hline $\begin{array}{l}\text { CDDP vs MTX vs } \\
\text { CDDP + MTX vs } \\
\text { CDDP + 5-FU }\end{array}$ & 200 & $\mathrm{~S}, \mathrm{R}$ & $\begin{array}{l}14 \text { vs } 6 \text { vs } \\
12 \text { vs } 11\end{array}$ & & $\begin{array}{l}7.2 \text { vs } 4.0 \text { vs } \\
5.0 \text { vs } 5.0 \text { (from } \\
\text { graph) }\end{array}$ & $\begin{array}{l}\text { CDDP superior to } \\
\text { MTX OS; } P=.025\end{array}$ & 29 \\
\hline $\begin{array}{l}\text { CDDP + 5-FU vs } \\
\text { CDDP + 5-FU + B + } \\
\text { MTX }\end{array}$ & 62 & $S, R$ & 38 vs 61 & FFS, 2.3 vs 4.5 & $\begin{array}{l}7.8, \text { no } \\
\text { significant } \\
\text { difference in } \\
\text { arms }\end{array}$ & $\begin{array}{l}\text { Underpowered } \\
\text { study }\end{array}$ & 82 \\
\hline $\begin{array}{l}\text { CDDP vs CDDP + } \\
5 \text {-FU vs CABO }\end{array}$ & 382 & $\mathrm{~S}, \mathrm{R}$ & $\begin{array}{l}15 \text { vs } 31 \\
\text { vs } 34\end{array}$ & $\begin{array}{l}\text { TTP, } 3 \text { vs } 4.3 \text { vs } \\
4.8\end{array}$ & $\begin{array}{l}6.7, \text { no } \\
\text { significant } \\
\text { difference in } \\
\text { arms }\end{array}$ & $\begin{array}{l}\text { TTP significant } \\
\text { only for CDDP vs } \\
\text { other arms }\end{array}$ & 83 \\
\hline MTX vs edatrexate & 264 & $\mathrm{~S}, \mathrm{R}$ & 16 vs 21 & TTP, 6.4 vs 6.1 & & & 84 \\
\hline MTX vs nolatrexed & 139 & $S, R, C$ & 11 vs 3 & TTP, 11.5 vs 1.9 & & & 85 \\
\hline $\begin{array}{l}\text { CDDP + 5-FU vs } \\
\text { CDDP + T }\end{array}$ & 218 & $\mathrm{~S}, \mathrm{R}$ & 27 vs 26 & & 8.7 vs 8.1 & $\begin{array}{l}\text { More high-grade } \\
\text { AEs with CDDP + } \\
\text { 5-FU }\end{array}$ & 34 \\
\hline $\begin{array}{l}\text { MTX vs gefitinib } \\
\text { (500) vs gefitinib } \\
(250)\end{array}$ & 486 & $\begin{array}{l}\text { Prior } \\
\text { platinum or } \\
\text { ineligible } \\
\text { for } \\
\text { platinum }\end{array}$ & $\begin{array}{l}3.9 \text { vs } 7.6 \\
\text { vs } 2.7\end{array}$ & & 6.7 vs 6.0 vs 5.6 & $\begin{array}{l}\text { In platinum-naïve } \\
\text { patients, MTX } \\
\text { OS superior to } \\
\text { gefitinib; HRs } 1.5 \\
\text { and } 1.6\end{array}$ & 30 \\
\hline $\begin{array}{l}\text { Zalutumumab vs } \\
\text { BSC }\end{array}$ & 286 & $\begin{array}{l}\mathrm{S}, \mathrm{R}, \mathrm{C} \\
\text { (all prior } \\
\text { platinum) }\end{array}$ & 6.3 vs 1.1 & 2.3 vs 1.9 & 6.7 vs 5.2 & $\begin{array}{l}6 \% \text { of controls } \\
\text { used MTX }\end{array}$ & 26 \\
\hline
\end{tabular}

Abbreviations: 5-FU, 5-fluorouracil; AE, adverse event; B, bleomycin; BSC, best supportive care; C, chemotherapy; CABO, cisplatin, methotrexate, bleomycin, and vincristine; CBCDA, carboplatin; CDDP, cisplatin; CTZ, cetuximab; D, docetaxel; FFS, failure-free survival; G, gemcitabine; HR, hazard ratio; L, liposomal doxorubicin; MTX, methotrexate; NA, not available; OS, overall survival; PB, cisplatin plus bleomycin; PD, progressive disease; PF, paclitaxel plus 5-FU; PFS, progression-free survival; TG, paclitaxel plus gemcitabine; TL, paclitaxel plus liposomal doxorubicin; R, radiation; RR, response rate; $\mathrm{S}$, surgery; $\mathrm{T}$, paclitaxel; $\mathrm{TTP}$, time to progression.

abold signifies a statistically significant difference cited in manuscript. 
Colevas

\begin{tabular}{|c|c|c|c|c|c|c|c|}
\hline Agents & $\mathrm{N}$ & $\begin{array}{l}\text { Prior } \\
\text { Treatments } \\
\text { for Most }\end{array}$ & $\begin{array}{l}\text { RR } \\
(\%)\end{array}$ & $\begin{array}{l}\text { Median } \\
\text { TTP or PFS } \\
(\mathrm{mo})\end{array}$ & $\begin{array}{l}\text { Median } \\
\text { OS } \\
\text { (mo) }\end{array}$ & Comments & Reference \\
\hline $\begin{array}{l}\text { Afatinib vs } \\
\text { methotrexate }\end{array}$ & 483 & $\begin{array}{l}S, R, C \text { (all } \\
\text { platinum- } \\
\text { exposed) }\end{array}$ & 10 vs 6 & 2.6 vs 1.7 & 6.8 vs 6.0 & & 95 \\
\hline Afatinib v CTZ & 121 & $\begin{array}{l}S, R, C \text { (all } \\
\text { platinum } \\
\text { refractory) }\end{array}$ & $\begin{array}{l}8.1 \text { vs } 9.7 \\
\text { by central } \\
\text { review }\end{array}$ & NA & NA & $\begin{array}{l}\text { Investigator } \\
\text { response } \\
\text { assessments, } 16.1 \\
\text { vs } 6.5\end{array}$ & 86 \\
\hline $\begin{array}{l}\text { CDDP vs CDDP + } \\
5-\mathrm{FU} \text { vs } 5-\mathrm{FU}\end{array}$ & 249 & & $\begin{array}{l}17 \text { vs } 32 \\
\text { vs } 13\end{array}$ & $\begin{array}{l}\text { TTP, } 2.0 \text { vs } 2.4 \\
\text { vs } 1.7\end{array}$ & $\begin{array}{l}\text { 5.7, no } \\
\text { difference } \\
\text { among arms }\end{array}$ & $\begin{array}{l}\text { Significant } \\
\text { difference, } \\
\text { combination vs } \\
\text { single-drug arms }\end{array}$ & 31 \\
\hline $\begin{array}{l}\text { CDDP vs CDDP + } \\
5-\mathrm{FU}+\mathrm{CTZ}\end{array}$ & 442 & $\begin{array}{l}\mathrm{S}, \mathrm{R}, 38 \% \\
\text { prior C }\end{array}$ & 20 vs 36 & 3.3 vs 5.6 & 7.4 vs 10.1 & $\begin{array}{l}\text { CDDP }+5-F U+/- \\
C T Z \times 6 \text { then } C T Z \\
\text { indefinitely until } \\
\text { PD }\end{array}$ & 8 \\
\hline $\begin{array}{l}\text { CDDP vs CDDP + } \\
\text { CTZ }\end{array}$ & 117 & $S, R$ & 10 vs 26 & 2.7 vs 4.2 & 8.0 vs 9.2 & $\begin{array}{l}\text { HR for OS same as } \\
\text { Ref. } 8\end{array}$ & 35 \\
\hline $\begin{array}{l}\text { CDDP + 5-FU vs } \\
\text { CDDP + 5-FU + } \\
\text { panitumumab }\end{array}$ & 657 & $\begin{array}{l}\mathrm{S}, \mathrm{R}, 81 \% \\
\text { prior } \mathrm{C}\end{array}$ & 26 vs 37 & 4.6 vs 5.8 & 9.0 vs 11.1 & $\begin{array}{l}\text { OS, PFS } \\
\text { improvement } \\
\text { in p16-negative } \\
\text { subset }\end{array}$ & 36 \\
\hline D vs $D+$ gefitinib & 270 & $S, R, C$ & 6 vs 13 & 2.1 vs 3.5 & 6.0 vs 7.3 & & 87 \\
\hline D vs $D+$ vandetanib & 29 & $\mathrm{R}, \mathrm{C}$ & 7 vs 13 & 0.8 vs 2.1 & 6.4 vs 5.7 & $\begin{array}{l}\text { Closed early for } \\
\text { futility }\end{array}$ & 88 \\
\hline$T+G$ vs $T+L$ & 166 & $S, R$, no C & 20 vs 29 & 4.4 vs 6.0 & 8.6 vs 11.5 & $\begin{array}{l}\text { Total treatment } \\
\text { cost: TG, } \$ 10,295 \text {; } \\
\text { TL, } \$ 15,358\end{array}$ & 39 \\
\hline
\end{tabular}

Abbreviations: 5-FU, 5-fluorouracil; AE, adverse event; B, bleomycin; BSC, best supportive care; C, chemotherapy; CABO, cisplatin, methotrexate, bleomycin, and vincristine; CBCDA, carboplatin; CDDP, cisplatin; CTZ, cetuximab; D, docetaxel; FFS, failure-free survival; G, gemcitabine; HR, hazard ratio; L, liposomal doxorubicin; MTX, methotrexate; NA, not available; OS, overall survival; PB, cisplatin plus bleomycin; PD, progressive disease; PF, paclitaxel plus 5-FU; PFS, progression-free survival; TG, paclitaxel plus gemcitabine; TL, paclitaxel plus liposomal doxorubicin; R, radiation; RR, response rate; $S$, surgery; $T$, paclitaxel; TTP, time to progression.

abold signifies a statistically significant difference cited in manuscript.

event rates, but when PF was compared with PT, substantially more high-grade adverse events occurred in the PF arm..$^{29,34}$ Therefore, the choice among these doublets should be based on patient-specific characteristics related to the adverse event profiles, such as hearing and kidney function and factors such as cost and complexity of treatment administration and supportive care.

Only one trial of multiagent chemotherapy has demonstrated statistically significant survival superiority versus another multiagent regimen in recurrent and/or metastatic SCCHN. In the EXTREME study, Vermorken et $\mathrm{al}^{8}$ randomized 442 patients in the firstline recurrent setting to either PF or PF plus cetuximab (PFC). The platinum agent used was either cisplatin or carboplatin, based on investigator choice. All patients received up to 6 cycles of PF or PFC. Patients continued indefinitely on cetuximab until disease progression. A statistically significant improvement was seen in response rates ( $20 \%$ vs $36 \%$ ), median PFS (3.3 vs 5.6 months), and median OS (7.4 vs 10.1 months), favoring the PFC arm. Adverse event profiles suggested that the addition of cetuximab was tolerable. These positive data are supported by a small randomized phase II study of cisplatin versus cisplatin plus cetuximab, which demonstrated similar hazard ratios favoring the addition of cetuximab to cisplatin but was not powered to demonstrate an OS difference..$^{35}$ However, how generalizable these results are for EGFR inhibitors in combination with cisplatin is unclear. A subsequent 657-patient study (SPECTRUM) investigating the addition of panitumumab to a chemotherapy backbone of PF demonstrated improvement in RR and PFS, but not OS. ${ }^{36}$ Whether the outcome differences between EXTREME and SPECTRUM were because the anti-EGFR monoclonal antibodies had a different effect or were due to differences in the clinical trial designs is unclear. More patients in the SPECTRUM 
Treatment of Metastatic Head and Neck Cancer

\section{Table 3 Selected Trials of Combination Therapy}

\begin{tabular}{|c|c|c|c|c|c|c|c|}
\hline Agents & $\mathbf{N}$ & Prior Treatment & $\begin{array}{l}\text { RR } \\
(\%)\end{array}$ & $\begin{array}{l}\text { Median } \\
\text { PFS or TTP } \\
(\mathrm{mo})\end{array}$ & $\begin{array}{l}\text { Median } \\
\text { OS } \\
\text { (mo) }\end{array}$ & Comments & Reference \\
\hline $\begin{array}{l}\text { Docetaxel + } \\
\text { cetuximab }\end{array}$ & 84 & $\begin{array}{l}\mathrm{S}, \mathrm{R}, \mathrm{C}(100 \% \\
\text { prior platinum) }\end{array}$ & 11 & 3.1 & 6.7 & & 89 \\
\hline $\begin{array}{l}\text { Paclitaxel + } \\
\text { cetuximab }\end{array}$ & 46 & $\mathrm{~S}, \mathrm{R}$ & 54 & 4.2 & 8.1 & $\begin{array}{l}\text { No prior palliative } \\
\text { treatment }\end{array}$ & 37 \\
\hline $\begin{array}{l}\text { Cisplatin + } \\
\text { docetaxel }\end{array}$ & 58 & $\mathrm{~S}, \mathrm{R}$ & 24 & 5.6 & 8.7 & $\begin{array}{l}\text { No prior palliative } \\
\text { treatment }\end{array}$ & 90 \\
\hline $\begin{array}{l}\text { Cisplatin + } \\
\text { docetaxel }\end{array}$ & 30 & $S, R, C$ & 17 & TTP, 3.5 & 9.2 & Both administered weekly & 91 \\
\hline $\begin{array}{l}\text { Cisplatin + } \\
\text { paclitaxel }\end{array}$ & 36 & $\mathrm{~S}, \mathrm{R}$ & 41 & TTP, 5.0 & 11.0 & $\begin{array}{l}\text { Cisplatin, } 75 \mathrm{mg} / \mathrm{m}^{2} \\
\text { Paclitaxel, } 175 \mathrm{mg} / \mathrm{m}^{2} \text { q21d }\end{array}$ & 92 \\
\hline $\begin{array}{l}\text { Docetaxel + } \\
\text { carboplatin }\end{array}$ & 68 & $\begin{array}{l}\mathrm{S}, \mathrm{R}, \text { no prior } \\
\text { platinum }\end{array}$ & 25 & PFS, 3.8 & $7.4 \mathrm{mo}$ & & 93 \\
\hline \multirow{2}{*}{$\begin{array}{l}\text { Paclitaxel + } \\
\text { carboplatin }\end{array}$} & \multirow[t]{2}{*}{31} & \multirow[t]{2}{*}{$S, R, C(65 \%)$} & \multirow[t]{2}{*}{52} & \multirow[t]{2}{*}{ PFS, 5.4} & \multirow[t]{2}{*}{12.8} & Paclitaxel, 80 mg/m² & \multirow[t]{2}{*}{94} \\
\hline & & & & & & $\begin{array}{l}\text { Carboplatin, AUC of } 2 \mathrm{mg} / \\
\mathrm{mL} / \mathrm{min} \text {, both weekly }\end{array}$ & \\
\hline
\end{tabular}

Abbreviations: AUC, area under the curve; C, chemotherapy; OS, overall survival; PFS, progression-free survival; R, radiation; RR, response rate; S, surgery; TTP, time to progression.

study had chemotherapy exposure before enrollment ( $81 \%$ vs $38 \%$ ), and the use of the anti-EGFR agent after chemotherapy completion was mandated in the EXTREME study but optional in SPECTRUM.

Whether the benefit seen with the addition of cetuximab to chemotherapy is platinum-specific is unknown. In a recent uncontrolled phase II study of paclitaxel and cetuximab in patients with prior platinum exposure, Hitt et $\mathrm{a}^{37}$ reported a $54 \%$ RR with a median OS of 8 months. Although this uncontrolled study does not prove that the clinical benefit of cetuximab in combination can be extended to nonplatinum regimens, this atypically high RR suggests that this question should be prioritized for subsequent trials. In regard to the EXTREME and SPECTRUM trials and their use of 5-FU as part of the backbone control regimen, it is also worth noting that taxanes were not approved for this indication in Belgium at the time EXTREME was conducted (J. Vermorken, personal communication). In the United States, the combination of PT plus cetuximab, therefore, although not formally studied or sanctioned by the FDA, is often substituted for PF plus cetuximab because of easier administration and the perceived better adverse event profile of PT.

\section{Cost-Effectiveness}

Because only one trial has demonstrated modest (2.7 months) survival improvement with the use of chemotherapy in the recurrent, metastatic setting, clinicians should consider other factors, such as the regimen's adverse event profile, patient convenience, and cost to the patient. Table 4 summarizes typical wholesale drug prices for 28 days of treatment based on the agents most commonly used in the United States, demonstrating a remarkable range from a low of $\$ 11$ for methotrexate to a high of $\$ 12,227$ for cetuximab. Using these estimates, drug cost alone for PF plus cetuximab for 6 cycles of treatment would be $\$ 74,328$ for a typical patient and $\$ 95,796$ if docetaxel were used instead of 5 -FU in this combination.

Overall costs are difficult to compare when so few large randomized trials have been performed, but some reports of randomized clinical trials have incorporated cost into the data analysis. An early randomized clinical trial comparing methotrexate with a combination of cisplatin, vincristine, and bleomycin $(\mathrm{COB})$ found that costs associated with one cycle of treatment were 4.3 times higher with $\mathrm{COB}$ despite no difference in response or survival rates. ${ }^{38}$ Although this analysis only included costs of administration, subsequent attempts at cost and efficacy analysis have become more sophisticated. Fountzilas et $\mathrm{l}^{39}$ performed a cost analysis of paclitaxel and gemcitabine versus paclitaxel plus pegylated liposomal doxorubicin in the first-line treatment of recurrent and/or metastatic SCCHN and found that the latter arm was more costly by $3649 \mathrm{EU}(\$ 5042)$ 


\begin{tabular}{|c|c|c|c|c|c|}
\hline Drug & Typical Regimen & Dosing & $\begin{array}{l}\text { Total } \\
\text { Monthly } \\
\text { Dose } \\
\text { (mg) }\end{array}$ & $\begin{array}{l}\text { Cost } \\
\text { per mg } \\
\text { (USD) }\end{array}$ & $\begin{array}{l}\text { Total Drug Price } \\
\text { for Example Patient } \\
\text { (USD) }\end{array}$ \\
\hline Cisplatin IV & $\begin{array}{l}\text { Cisplatin and 5-FU } \\
\text { q28d }\end{array}$ & $100 \mathrm{mg} / \mathrm{m}^{2}$ & 200 & $\$ 0.43$ & $\$ 87$ \\
\hline Carboplatin IV & $\begin{array}{l}\text { Carboplatin and } \\
5 \text {-FU q28d }\end{array}$ & $\begin{array}{l}\text { AUC of } \\
6 \mathrm{mg} / \mathrm{mL} / \mathrm{min}\end{array}$ & 619 & $\$ 0.20$ & $\$ 123$ \\
\hline Docetaxel IV & Docetaxel q21d & $75 \mathrm{mg} / \mathrm{m}^{2}$ & 200 & $\$ 18.26$ & $\$ 3,652$ \\
\hline Paclitaxel IV & $\begin{array}{l}\text { Cisplatin and } \\
\text { paclitaxel q21d }\end{array}$ & $175 \mathrm{mg} / \mathrm{m}^{2}$ & 467 & $\$ 0.67$ & $\$ 314$ \\
\hline 5-FU IV & $\begin{array}{l}\text { Cisplatin and 5-FU } \\
\text { q28d }\end{array}$ & $\begin{array}{l}1000 \mathrm{mg} / \mathrm{m}^{2} / \mathrm{d} \\
\times 4 \mathrm{~d}\end{array}$ & 8000 & $\$ 0.01$ & $\$ 74$ \\
\hline \multirow[t]{2}{*}{ Capecitabine PO } & $\begin{array}{l}\text { Capecitabine bid } x \\
14 d \text { then off } x 7 d\end{array}$ & $\begin{array}{l}1000 \mathrm{mg} / \mathrm{m}^{2} \\
\text { bid }\end{array}$ & 150 tablets & $\$ 39.88^{b}$ & $\$ 5,982$ \\
\hline & & $\begin{array}{l}\text { ( } 4 \text { tablets, } \\
500 \text { mg each) }\end{array}$ & & & \\
\hline Methotrexate IV & $\begin{array}{l}\text { Methotrexate q7d } \\
\text { IV }\end{array}$ & $40 \mathrm{mg} / \mathrm{m}^{2}$ & 240 & $\$ 0.05$ & $\$ 11$ \\
\hline Cetuximab IV & $\begin{array}{l}\text { Cisplatin, 5-FU with } \\
\text { weekly cetuximab }\end{array}$ & $250 \mathrm{mg} / \mathrm{m}^{2}$ & 2000 & $\$ 6.11$ & $\$ 12,227$ \\
\hline
\end{tabular}

Prices from Lexicomp as of 4/22/2014: Pricing (Medi-Span): the pricing data provided represent the median average wholesale price (AWP) and/or average of AWP price for brand and/or generic product, respectively.

Abbreviations: 5-FU, 5-fluorouracil; AUC, area under the curve; IV, intravenous; PO, by mouth.

aBased on a 6-foot-tall, 165-lb, 60-year-old man with a body surface area of $2 \mathrm{~m}^{2}$ and a serum creatinine level of $1 \mathrm{mg} / \mathrm{dL}$, AUC using the CockcroftGault formula.

${ }^{\mathrm{b} C o s t}$ per 500-mg tablet.

Data from Lexicomp Online. Available at: https://online.lexi.com/lco/action/doc/retrieve/docid/patch_f/7270. Accessed April 22, 2014.

when including all treatment and adverse eventrelated expenses despite no survival difference. More recently, 2 groups of investigators have attempted to evaluate the cost per life year gained and qualityadjusted life year (QALY) gained from the addition of cetuximab to the backbone of cisplatin and 5-FU based on the results of the EXTREME study ${ }^{40,41}$ They found that the incremental cost-effectiveness was 92,226 GBP $(\$ 154,919)$ for each life year gained and 121,367 GBP $(\$ 203,879)$ per QALY. They concluded that the use of cetuximab in this setting was not cost-effective and not recommended because the costs were substantially higher than those normally acceptable to the British National Health Service.

\section{Biomarkers as Predictors of Clinical Benefit}

The past decade has seen major advances in the treatment of several cancers through the use of predictive biomarkers, such as HER2/neu overexpression as a predictor of response to trastuzumab in breast cancer, and EGFR mutation as a predictor of response to erlotinib in nonsmall cell lung cancer. Although there are markers and panels of markers that, when evaluated over the treatment and follow-up interval, can predict therapeutic responses in patients with SCCHN, ${ }^{42-45}$ no markers yet exist that have robustly demonstrated utility in terms of chemotherapy selection. Examples of candidates for these biomarkers include ERCC1 protein or mRNA levels as predictors of resistance to platinum compounds, but the data are inconsistent and antibody reagents for ERCC1 have been problematic. ${ }^{46,47}$ Thymidine synthase (TS) and thymidine phosphorylase (TP) have been investigated as potential markers of 5-FU benefit without conclusive or consistent results. ${ }^{48}$

More recently, a shift has occurred from biochemical-based to genetics-based assays, and 
even whole-genome sequencing is advocated by some as a rational and often "actionable" approach to drug benefit prediction. As discussed, although a few examples exist in which genetic alterations have proved useful in other cancers, no validated markers exist for selecting among treatment choices for recurrent and/or metastatic SCCHN. Most genetic alterations in SCCHN are loss of function of tumor suppressor genes in the TP53, CDKN2A, and PTEN pathways. These alterations are not presently easily targetable by drugs, because restoring function as an anticancer strategy has not yet been possible. ${ }^{49}$ Similarly, for the recently discovered NOTCH1inactivating mutations in SCCHN ( $\approx 12 \%-19 \%)$, no specific therapy exists to restore function. ${ }^{49-51}$ Claims that up to $80 \%$ of oral cavity squamous cell carcinoma have targetable genetic alterations, for example, are based on biological plausibility concerning agents against these targets, rather than clinical demonstration of efficacy. ${ }^{52,53}$ Emerging targets of interest include FGFR, HER2, MET, $\mathrm{PI} 3 \mathrm{~K}$, and mTOR, but the promise of benefit from inhibiting these targets has yet to be realized. ${ }^{54,55}$ Despite the large amount of advertising for the use of these genomic and genetic screening assays, reported improvements in outcome are limited to a small minority of highly selected patients. Therefore, use of these assays to determine treatment should be limited to the context of experimental treatment. Widespread ad hoc use should be discouraged.

Over the past decade it has become clear that HPV-related oropharyngeal squamous cell carcinomas are a clinically unique subset of SCCHN, with a much better prognosis. Results of the SPECTRUM trial, using p16 immunohistochemistry as a surrogate for HPV, suggest that for panitumumab, benefit may be limited to the p16-negative patients, but a retrospective evaluation of a subset of patients in the EXTREME trial demonstrated no association between p16 or HPV and OS or PFS benefit for cetuximab. ${ }^{36,56}$ Therefore, although $\mathrm{p} 16 / \mathrm{HPV}$ seems to be prognostic in recurrent and/or metastatic SCCHN, data do not yet support a benefit prediction role for $\mathrm{p} 16 / \mathrm{HPV}$ in this population with respect to systemic therapy treatment, and the data are conflicting for anti-EGFR1 monoclonal antibodies.

\section{Practical Treatment Advice}

\section{Single Agents}

Methotrexate and paclitaxel are appropriate initial single-agent choices for patients with recurrent and/or metastatic SCCHN. These agents have the advantage of good patient tolerability, have wellestablished track records of relevant anticancer activity, and are not overly burdensome in terms of administration. 5-FU is also an appropriate agent, but the need for continuous infusion is a significant burden for many patients. Capecitabine, cetuximab, and docetaxel also have reasonable anticancer activity; however, their high cost precludes their recommendation over much less expensive choices. This approach is favored especially after early relapse from cisplatin-based chemoradiation treatment, when rechallenge with a platinum is unlikely to be beneficial. The taxanes can be dosed either on a weekly or every-21-day schedule, but the weekly schedule has the advantage of better tolerability and less irrevocable toxicity per dose, so the clinician has the option to modify dosing more frequently based on patient tolerability issues. Table 5 lists recommended doses and schedules of administration. It is common, especially in pretreated patients, to hold taxane dosing every few weeks on an as-needed basis because of cumulative bone marrow toxicity. Cisplatin and carboplatin are generally not used as single agents. Cisplatin especially has a worse adverse event profile than the agents listed earlier and therefore, without convincing evidence of superiority versus methotrexate or the taxanes, should not be used alone.

\section{Multiagent Treatment}

For patients with good performance status and appropriate organ function (ie, renal, hepatic) with rapidly progressive or symptomatic disease, triple-agent treatment with PFC or PT plus cetuximab (PTC) (Table 5) may be appropriate, but one must balance the markedly increased adverse event profile and cost of these multidrug combinations against the promise of modest median OS extension. Many favor PTC over PFC because of its better tolerability and the infusion pump requirement with 5-FU, despite the fact that a taxane triplet has not been evaluated in a phase II study and therefore is not supported by level 1 evidence per the NCCN Clinical Practice Guidelines in Oncology for Head and Neck Cancers. ${ }^{57}$ 
Table 5 Commonly Used Systemic Treatment Options for Patients With Recurrent and/or Metastatic Head and Neck Squamous Cell Carcinoma

\begin{tabular}{|c|c|c|}
\hline Regimen & Dose & Schedule \\
\hline Methotrexate & $40-60 \mathrm{mg} / \mathrm{m}^{2} \mathrm{IV}$ & Weekly indefinitely \\
\hline Paclitaxel & $80-90 \mathrm{mg} / \mathrm{m}^{2} \mathrm{IV}$ & Weekly indefinitely \\
\hline Docetaxel & $25-30 \mathrm{mg} / \mathrm{m}^{2} \mathrm{IV}$ & Weekly indefinitely \\
\hline \multicolumn{3}{|l|}{ PFC } \\
\hline Cisplatin or carboplatin & $\begin{array}{l}\text { Cisplatin, } 100 \mathrm{mg} / \mathrm{m}^{2} \mathrm{IV} \\
\text { carboplatin, AUC of } 5 \mathrm{mg} / \mathrm{mL} / \mathrm{min} \text { IV day } 1\end{array}$ & $q 21 d \times 6$ \\
\hline $5-\mathrm{FU}$ & $5-\mathrm{FU}, 1000 \mathrm{mg} / \mathrm{m}^{2} / \mathrm{d} \times 4 \mathrm{~d} \mathrm{IVCl}$ days $1-4$ & $q 21 d \times 6$ \\
\hline Cetuximab & Cetuximab, $400 \mathrm{mg} / \mathrm{m}^{2}$ IV day 1 , then $250 \mathrm{mg} / \mathrm{m}^{2} \mathrm{IV}$ & Weekly indefinitely \\
\hline \multicolumn{3}{|l|}{ PTC } \\
\hline Cisplatin & Cisplatin, $75 \mathrm{mg} / \mathrm{m}^{2} \mathrm{IV}$ day 1 & q21d \\
\hline Paclitaxel & Paclitaxel, 75 mg/m² IV day 1 & q21d \\
\hline Cetuximab & Cetuximab, $400 \mathrm{mg} / \mathrm{m}^{2}$ IV day 1 , then $250 \mathrm{mg} / \mathrm{m}^{2}$ IV & Weekly indefinitely \\
\hline
\end{tabular}

Abbreviations: 5-FU, 5-fluorouracil; AUC, area under the curve; IV, intravenous; IVCl, intravenous continuous infusion; PFC, cisplatin/carboplatin, 5-FU, cetuximab; PTC, cisplatin, paclitaxel, cetuximab.

Finally, although many patients benefit from these standard treatments, knowledge remains limited because so few definitive adequately powered studies have been performed. Patients and clinicians should be encouraged to participate both in trials of new promising experimental agents and in trials whose purpose is to better define the role of currently available treatments.

\section{References}

1. Cancer Facts \& Figures 2014. Available at: http://www.cancer.org/research/ cancerfactsstatistics/cancerfactsfigures2014/. Accessed April 21, 2015.

2. Stewart B, Wild CP, eds. World Cancer Report 2014. Lyon, France: International Agency for Research on Cancer; 2014

3. Lan Q, Chapman RS, Schreinemachers DM, et al. Household stove improvement and risk of lung cancer in Xuanwei, China. J Natl Cancer Inst 2002;94:826-835

4. Chaturvedi AK, Anderson WF, Lortet-Tieulent J, et al. Worldwide trends in incidence rates for oral cavity and oropharyngeal cancers. J Clin Oncol 2013;31:4550-4559.

5. Tiwana MS, Wu J, Hay J, et al. 25 year survival outcomes for squamous cell carcinomas of the head and neck: population-based outcomes from a Canadian province. Oral Oncol 2014;50:651-656.

6. Eisenhauer EA, Therasse P, Bogaerts J, et al. New response evaluation criteria in solid tumours: revised RECIST guideline (version 1.1). Eur J Cancer 2009;45:228-247.

7. Morton RP, Rugman F, Dorman EB, et al. Cisplatinum and bleomycin for advanced or recurrent squamous cell carcinoma of the head and neck: a randomised factorial phase III controlled trial. Cancer Chemother Pharmacol 1985;15:283-289

8. Vermorken JB, Mesia R, Rivera F, et al. Platinum-based chemotherapy plus cetuximab in head and neck cancer. N Engl J Med 2008;359:1116-1127.

9. Colevas $\mathrm{AD}$. Chemotherapy options for patients with metastatic or recurrent squamous cell carcinoma of the head and neck. J Clin Oncol 2006;24:2644 2652.

10. Fury MG, Pfister DG. Current recommendations for systemic therapy of recurrent and/or metastatic head and neck squamous cell cancer. J Natl Compr Canc Netw 2011;9:681-689.
11. Shin DM, Khuri FR. Advances in the management of recurrent or metastatic squamous cell carcinoma of the head and neck. Head Neck 2013;35:443-453.

12. Machiels JP, Schmitz S. Management and palliative chemotherapy for metastatic or recurrent squamous cell carcinoma of the head and neck. Expert Rev Anticancer Ther 2011;11:359-371.

13. Price KA, Cohen EE. Current treatment options for metastatic head and neck cancer. Curr Treat Options Oncol 2012;13:35-46.

14. Licitra L, Bergamini C, Mirabile A, et al. Targeted therapy in head and neck cancer. Curr Opin Otolaryngol Head Neck Surg 2011;19:132-137.

15. Molin Y, Fayette J. Current chemotherapies for recurrent/metastatic head and neck cancer. Anticancer Drugs 2011;22:621-625.

16. Forastiere AA, Metch B, Schuller DE, et al. Randomized comparison of cisplatin plus fluorouracil and carboplatin plus fluorouracil versus methotrexate in advanced squamous-cell carcinoma of the head and neck: a Southwest Oncology Group study. J Clin Oncol 1992;10:1245-1251.

17. Carter SK. The chemotherapy of head and neck cancer. Semin Oncol 1977;4:413-424

18. Saxman S, Mann B, Canfield V, et al. A phase II trial of vinorelbine in patients with recurrent or metastatic squamous cell carcinoma of the head and neck. Am J Clin Oncol 1998;21:398-400.

19. Bertino JR, Mosher MB, DeConti RC. Chemotherapy of cancer of the head and neck. Cancer 1973;31:1141-1149.

20. Catimel G, Vermorken JB, Clavel M, et al. A phase II study of gemcitabine (LY 188011) in patients with advanced squamous cell carcinoma of the head and neck. EORTC Early Clinical Trials Group. Ann Oncol 1994;5:543-547.

21. Saloura V, Cohen EE, Licitra $L$, et al. An open-label single-arm, phase II trial of zalutumumab, a human monoclonal anti-EGFR antibody, in patients with platinum-refractory squamous cell carcinoma of the head and neck. Cancer Chemother Pharmacol 2014;73:1227-1239.

22. Vermorken JB, Trigo J, Hitt R, et al. Open-label, uncontrolled, multicenter phase II study to evaluate the efficacy and toxicity of cetuximab as a single agent in patients with recurrent and/or metastatic squamous cell carcinoma of the head and neck who failed to respond to platinum-based therapy. J Clin Oncol 2007;25:2171-2177

23. Soulieres D, Senzer NN, Vokes EE, et al. Multicenter phase II study of erlotinib, an oral epidermal growth factor receptor tyrosine kinase inhibitor, in patient with recurrent or metastatic squamous cell cancer of the head and neck. J Clin Oncol 2004;22:77-85

24. Cohen EE, Rosen F, Stadler WM, et al. Phase II trial of ZD1839 in recurrent or metastatic squamous cell carcinoma of the head and neck. J Clin Oncol 2003;21:1980-1987.

25. Perez CA, Song H, Raez LE, et al. Phase II study of gefitinib adaptive dose escalation to skin toxicity in recurrent or metastatic squamous cell carcinoma of the head and neck. Oral Oncol 2012;48:887-892. 
26. Machiels JP, Subramanian S, Ruzsa A, et al. Zalutumumab plus best supportive care versus best supportive care alone in patients with recurrent or metastatic squamous-cell carcinoma of the head and neck after failure of platinumbased chemotherapy: an open-label, randomised phase 3 trial. Lancet Oncol 2011;12:333-343.

27. Hong WK, Schaefer S, Issell B, et al. A prospective randomized trial of methotrexate versus cisplatin in the treatment of recurrent squamous cell carcinoma of the head and neck. Cancer 1983;52:206-210.

28. Grose WE, Lehane DE, Dixon DO, et al. Comparison of methotrexate and cisplatin for patients with advanced squamous cell carcinoma of the head and neck region: a Southwest Oncology Group Study. Cancer Treat Rep 1985;69:577-581.

29. A phase III randomised trial of cisplatinum, methotrexate, cisplatinum + methotrexate and cisplatinum +5 -FU in end stage squamous carcinoma of the head and neck. Liverpool Head and Neck Oncology Group. Br J Cancer 1990;61:311-315.

30. Stewart IS, Cohen EE, Licitra L, et al. Phase III study of gefitinib compared with intravenous methotrexate for recurrent squamous cell carcinoma of the head and neck [corrected]. J Clin Oncol 2009;27:1864-1871.

31. Jacobs C, Lyman G, Velez-Garcia E, et al. A phase III randomized study comparing cisplatin and fluorouracil as single agents and in combination for advanced squamous cell carcinoma of the head and neck. J Clin Oncol 1992;10:257-263.

32. Guardiola E, Peyrade F, Chaigneau L, et al. Results of a randomised phase II study comparing docetaxel with methotrexate in patients with recurrent head and neck cancer. Eur J Cancer 2004;40:2071-2076.

33. Campbell JB, Dorman EB, McCormick M, et al. A randomized phase III trial of cisplatinum, methotrexate, cisplatinum + methotrexate, and cisplatinum +5 -fluoro-uracil in end-stage head and neck cancer. Acta Otolaryngol 1987;103:519-528.

34. Gibson MK, Li Y, Murphy B, et al. Randomized phase III evaluation of cisplatin plus fluorouracil versus cisplatin plus paclitaxel in advanced head and neck cancer (E1395): an intergroup trial of the Eastern Cooperative Oncology Group. J Clin Oncol 2005;23:3562-3567.

35. Burtness B, Goldwasser MA, Flood W, et al. Phase III randomized trial of cisplatin plus placebo compared with cisplatin plus cetuximab in metastatic/ recurrent head and neck cancer: an Eastern Cooperative Oncology Group study. J Clin Oncol 2005;23:8646-8654.

36. Vermorken JB, Stohlmacher-Williams J, Davidenko I, et al. Cisplatin and fluorouracil with or without panitumumab in patients with recurrent or metastatic squamous-cell carcinoma of the head and neck (SPECTRUM): an open-label phase 3 randomised trial. Lancet Oncol 2013;14:697-710.

37. Hitt $\mathrm{R}$, Irigoyen $\mathrm{A}$, Cortes-Funes $\mathrm{H}$, et al. Phase II study of the combination of cetuximab and weekly paclitaxel in the first-line treatment of patients with recurrent and/or metastatic squamous cell carcinoma of head and neck. Ann Oncol 2012;23:1016-1022.

38. Drelichman A, Cummings G, Al-Sarraf M. A randomized trial of the combination of cis-platinum, oncovin and bleomycin (COB) versus methotrexate in patients with advanced squamous cell carcinoma of the head and neck. Cancer 1983;52:399-403.

39. Fountzilas G, Papakostas P, Dafni U, et al. Paclitaxel and gemcitabine vs. paclitaxel and pegylated liposomal doxorubicin in advanced nonnasopharyngeal head and neck cancer. An efficacy and cost analysis randomized study conducted by the Hellenic Cooperative Oncology Group. Ann Oncol 2006;17:1560-1567.

40. Bagust A, Greenhalgh J, Boland A, et al. Cetuximab for recurrent and/ or metastatic squamous cell carcinoma of the head and neck: a NICE single technology appraisal. Pharmacoeconomics 2010;28:439-448.

41. Hannouf MB, Sehgal $C$, Cao JQ, et al. Cost-effectiveness of adding cetuximab to platinum-based chemotherapy for first-line treatment of recurrent or metastatic head and neck cancer. PLoS One 2012;7:e38557.

42. Bigbee WL, Grandis JR, Siegfried JM. Multiple cytokine and growth factor serum biomarkers predict therapeutic response and survival in advanced-stage head and neck cancer patients. Clin Cancer Res 2007;13:3107-3108.

43. Bradford CR, Kumar B, Bellile E, et al. Biomarkers in advanced larynx cancer Laryngoscope 2014;124:179-187.

44. Moreno-Galindo C, Hermsen M, Garcia-Pedrero JM, et al. p27 and BCL2 expression predicts response to chemotherapy in head and neck squamous cell carcinomas. Oral Oncol 2014;50:128-134.

45. Shiga $\mathrm{H}$, Heath EI, Rasmussen AA, et al. Prognostic value of $\mathrm{p} 53$, glutathione S-transferase pi, and thymidylate synthase for neoadjuvant cisplatin-based chemotherapy in head and neck cancer. Clin Cancer Res 1999;5:4097-4104

46. Choi IJ, Kim DW, Kim DY, et al. Predictive markers for neoadjuvant chemotherapy in advanced squamous cell carcinoma of maxillary sinus: Preliminary report. Acta Otolaryngol 2013;133:291-296.
47. Koh Y, Kim TM, Jeon YK, et al. Class III beta-tubulin, but not ERCC1, is a strong predictive and prognostic marker in locally advanced head and neck squamous cell carcinoma. Ann Oncol 2009;20:1414-1419.

48. Lee S, Park $\mathrm{YH}, \mathrm{Kim} \mathrm{KH}$, et al. Thymidine synthase, thymidine phosphorylase, and excision repair cross-complementation group 1 expression as predictive markers of capecitabine plus cisplatin chemotherapy as first-line treatment for patients with advanced oesophageal squamous cell carcinoma. Br J Cancer 2010;103:845-851.

49. Mountzios G, Rampias T, Psyrri A. The mutational spectrum of squamous-cell carcinoma of the head and neck: targetable genetic events and clinical impact. Ann Oncol 2014;25:1889-1900.

50. Agrawal N, Frederick MJ, Pickering CR, et al. Exome sequencing of head and neck squamous cell carcinoma reveals inactivating mutations in NOTCH1. Science 2011;333:1154-1157.

51. Stransky N, Egloff AM, Tward AD, et al. The mutational landscape of head and neck squamous cell carcinoma. Science 2011;333:1157-1160.

52. Pickering CR, Zhang J, Yoo SY, et al. Integrative genomic characterization of oral squamous cell carcinoma identifies frequent somatic drivers. Cancer Discov 2013;3:770-781.

53. Burtness B, Bauman JE, Galloway T. Novel targets in HPV-negative head and neck cancer: overcoming resistance to EGFR inhibition. Lancet Oncol 2013;14:e302-309.

54. Gaykalova DA, Mambo E, Choudhary A, et al. Novel insight into mutational landscape of head and neck squamous cell carcinoma. PLoS One 2014;9:e93102.

55. Bauman JE, Arias-Pulido H, Lee SJ, et al. A phase II study of temsirolimus and erlotinib in patients with recurrent and/or metastatic, platinum-refractory head and neck squamous cell carcinoma. Oral Oncol 2013;49:461-467.

56. Vermorken JB, Psyrri A, Mesia R, et al. Impact of tumor HPV status on outcome in patients with recurrent and/or metastatic squamous cell carcinoma of the head and neck receiving chemotherapy with or without cetuximab: retrospective analysis of the phase III EXTREME trial. Ann Oncol 2014;25:801-807.

57. Pfister DG, Spencer S, Brizel DM, et al. NCCN Clinical Practice Guidelines in Oncology for Head and Neck Cancers. Version 2, 2014. Available at: NCCN .org. Accessed April 21, 2015.

58. Wittes RE, Cvitkovic E, Shah J, et al. CIS-Dichlorodiammineplatinum(II) in the treatment of epidermoid carcinoma of the head and neck. Cancer Treat Rep 1977;61:359-366.

59. Tarpley JL, Chretien PB, Alexander JC Jr, et al. High dose methotrexate as a preoperative adjuvant in the treatment of epidermoid carcinoma of the head and neck. A feasibility study and clinical trial. Am J Surg 1975;130:481-486.

60. Bell R, Sullivan JR, Fleming WB, et al. Results of treatment of head and neck carcinoma with high dose methotrexate. Clin Exp Pharmacol Physiol Suppl 1979;5:23-27.

61. Woods RL, Fox RM, Tattersall MH. Methotrexate treatment of advanced head and neck cancers: a dose response evaluation. Cancer Treat Rep 1981;65(Suppl 1):155-159.

62. Raguse JD, Gath HJ, Bier J, et al. Gemcitabine in the treatment of advanced head and neck cancer. Clin Oncol (R Coll Radiol) 2005;17:425-429.

63. Forastiere AA, Shank D, Neuberg D, et al. Final report of a phase II evaluation of paclitaxel in patients with advanced squamous cell carcinoma of the head and neck: an Eastern Cooperative Oncology Group trial (PA390). Cancer 1998;82:2270-2274

64. Tahara M, Minami $\mathrm{H}$, Hasegawa $\mathrm{Y}$, et al. Weekly paclitaxel in patients with recurrent or metastatic head and neck cancer. Cancer Chemother Pharmacol 2011;68:769-776

65. Specenier P, Rasschaert M, Vroman $\mathrm{P}$, et al. Weekly docetaxel in patients with recurrent and/or metastatic squamous cell carcinoma of the head and neck. Am J Clin Oncol 2011;34:472-477.

66. Cho BC, Keum KC, Shin SJ, et al. Weekly docetaxel in patients with platinumrefractory metastatic or recurrent squamous cell carcinoma of the head and neck. Cancer Chemother Pharmacol 2009;65:27-32.

67. Hitt R, Amador ML, Quintela-Fandino M, et al. Weekly docetaxel in patients with recurrent and/or metastatic squamous cell carcinoma of the head and neck. Cancer 2006;106:106-111.

68. Dreyfuss AI, Clark JR, Norris CM, et al. Docetaxel: an active drug for squamous cell carcinoma of the head and neck. J Clin Oncol 1996;14:1672-1678.

69. Catimel G, Verweij J, Mattijssen V, et al. Docetaxel (Taxotere): an active drug for the treatment of patients with advanced squamous cell carcinoma of the head and neck. EORTC Early Clinical Trials Group. Ann Oncol 1994;5:533537.

70. Thomas F, Rochaix P, Benlyazid A, et al. Pilot study of neoadjuvant treatment with erlotinib in nonmetastatic head and neck squamous cell carcinoma. Clin Cancer Res 2007;13:7086-7092. 
71. Gebbia V, Testa A, Valenza R, et al. A pilot study of vinorelbine on a weekly schedule in recurrent and/or metastatic squamous cell carcinoma of the head and neck. Eur J Cancer 1993;29A:1358-1359.

72. Testolin A, Recher G, Cristoferi V, et al. Vinorelbine in pre-treated advanced head \& neck squamous cell carcinoma. A phase II study. Invest New Drugs 1994;12:231-234

73. Inuyama $\mathrm{Y}$, Kida $\mathrm{A}$, Tsukuda $\mathrm{M}$, et al. Early phase II study of $\mathrm{S}-1$ in patients with advanced head and neck cancer. S-1 Cooperative Study Group (Head and Neck Working Group) [in Japanese]. Gan To Kagaku Ryoho 1998;25:11511158 .

74. Colevas AD, Amrein PC, Gomolin H, et al. A phase II study of combined oral uracil and ftorafur with leucovorin for patients with squamous cell carcinoma of the head and neck. Cancer 2001;92:326-331.

75. Martinez-Trufero J, Isla D, Adansa JC, et al. Phase II study of capecitabine as palliative treatment for patients with recurrent and metastatic squamous head and neck cancer after previous platinum-based treatment. Br J Cancer 2010;102:1687-1691.

76. Buesa JM, Fernandez R, Esteban E, et al. Phase II trial of ifosfamide in recurrent and metastatic head and neck cancer. Ann Oncol 1991;2:151-152.

77. Vogl SE, Schoenfeld DA, Kaplan BH, et al. A randomized prospective comparison of methotrexate with a combination of methotrexate, bleomycin, and cisplatin in head and neck cancer. Cancer 1985;56:432-442.

78. Williams SD, Velez-Garcia E, Essessee I, et al. Chemotherapy for head and neck cancer. Comparison of cisplatin + vinblastine + bleomycin versus methotrexate. Cancer 1986;57:18-23.

79. Jacobs C, Meyers F, Hendrickson C, et al. A randomized phase III study of cisplatin with or without methotrexate for recurrent squamous cell carcinoma of the head and neck. A Northern California Oncology Group study. Cancer 1983;52:1563-1569.

80. Airoldi M, Pedani F, Brando V, et al. Comparison of methotrexate and sequential methotrexate-5-fluorouracil for patients with recurrent squamous cell carcinoma of the oral cavity. Chemioterapia 1987;6:390-392.

81. Chauvergne J, Cappelaere $P$, Fargeot $P$, et al. A randomized study comparing cisplatin alone or combined in the palliative treatment of carcinoma of the head and neck. Analysis of a series of 209 patients [in French]. Bull Cancer 1988;75:9-22.

82. Amrein PC, Fabian RL. Treatment of recurrent head and neck cancer with cisplatin and 5-fluorouracil vs. the same plus bleomycin and methotrexate. Laryngoscope 1992;102:901-906.

83. $\mathrm{M}$, Vermorken JB, Cognetti F, et al. Randomized comparison of cisplatin, methotrexate, bleomycin and vincristine $(\mathrm{CABO})$ versus cisplatin and 5-fluorouracil (CF) versus cisplatin (C) in recurrent or metastatic squamous cell carcinoma of the head and neck. A phase III study of the EORTC Head and Neck Cancer Cooperative Group. Ann Oncol 1994;5:521-526.

84. Schornagel JH, Verweij J, de Mulder PH, et al. Randomized phase III trial of edatrexate versus methotrexate in patients with metastatic and/or recurrent squamous cell carcinoma of the head and neck: a European Organization for
Research and Treatment of Cancer Head and Neck Cancer Cooperative Group study. J Clin Oncol 1995;13:1649-1655.

85. Pivot X, Wadler S, Kelly C, et al. Result of two randomized trials comparing nolatrexed (Thymitaq) versus methotrexate in patients with recurrent head and neck cancer. Ann Oncol 2001;12:1595-1599.

86. Cupissol D, Seiwart T, Fayette J, et al. A randomized, open-label, phase II study of afatinib versus cetuximab in patients (pts) with recurrent or metastatic (R/M) head and neck squamous cell carcinoma (HNSCC): analysis of stage 2 (S2) following crossover [abstract]. J Clin Oncol 2013;31(Suppl):Abstract 6001.

87. Argiris A, Ghebremichael M, Gilbert J, et al. Phase III randomized, placebocontrolled trial of docetaxel with or without gefitinib in recurrent or metastatic head and neck cancer: an eastern cooperative oncology group trial. J Clin Oncol 2013;31:1405-1414.

88. Limaye S, Riley S, Zhao S, et al. A randomized phase II study of docetaxel with or without vandetanib in recurrent or metastatic squamous cell carcinoma of head and neck (SCCHN). Oral Oncol 2013;49:835-841.

89. Knoedler M, Gauler TC, Gruenwald V, et al. Phase II study of cetuximab in combination with docetaxel in patients with recurrent and/or metastatic squamous cell carcinoma of the head and neck after platinum-containing therapy: a multicenter study of the Arbeitsgemeinschaft Internistische Onkologie. Oncology 2013;84:284-289.

90. Chang PM, Tzeng $\mathrm{CH}$, Chen $\mathrm{MH}$, et al. Triweekly reduced-dose docetaxel combined with cisplatin in recurrent/metastatic head and neck squamous cell carcinoma: a multicenter phase II study. Cancer Chemother Pharmacol 2011;68:1477-1484.

91. Guntinas-Lichius $O$, Ruhlow $S$, Veelken F, et al. Quality of life during first-line palliative chemotherapy for recurrent and metastatic head and neck cancer with weekly cisplatin and docetaxel. J Cancer Res Clin Oncol 2009;135:901-908.

92. Adamo V, Ferraro G, Pergolizzi S, et al. Paclitaxel and cisplatin in patients with recurrent and metastatic head and neck squamous cell carcinoma. Oral Oncol 2004;40:525-531.

93. Samlowski WE, Moon J, Kuebler JP, et al. Evaluation of the combination of docetaxel/carboplatin in patients with metastatic or recurrent squamous cell carcinoma of the head and neck (SCCHN): a Southwest Oncology Group Phase II study. Cancer Invest 2007;25:182-188.

94. Moosmann P, Egli F, Stahel RA, et al. Weekly paclitaxel and carboplatin combination chemotherapy in patients with advanced squamous cell carcinoma of the head and neck. Onkologie 2003;26:568-572.

95. Machiels JP, Haddad RI, Fayette J, et al. Afatinib versus methotrexate as second-line treatment in patients with recurrent or metastatic squamous-cell carcinoma of the head and neck progressing on or after platinum-based therapy (LUX-Head \& Neck 1): an open-label, randomised phase 3 trial. Lancet Oncol 2015;16:583-594. 